\title{
Mikania cordata leaves extract promotes activity against pathogenic bacteria and anticancer activity in EAC cell-bearing swiss albino mice
}

\author{
Md. Mashiar Rahman ${ }^{1 *}$, Md. Masnoon Kabir ${ }^{1}$, Md. Abdullah AL Noman ${ }^{1}$, Md. Rakibul Islam¹, Biplab Kumar Dash', \\ Shahina Akhter ${ }^{2}$, Mohammad Jashim Uddin ${ }^{3}$, Atiqur Rahman ${ }^{4}$ \\ ${ }^{1}$ Molecular and Cellular Biology Laboratory, Department of Genetic Engineering and Biotechnology, Jashore University of Science and Technology, Jashore \\ 7408, Bangladesh. \\ ${ }^{2}$ Department of Biochemistry and Biotechnology, University of Science and Technology Chittagong, Foys Lake, Chittagong 4202, Bangladesh. \\ ${ }^{3}$ Department of Pharmacy, Jashore University of Science and Technology, Jashore 7408, Bangladesh. \\ ${ }^{4}$ Department of Applied Chemistry and Chemical Engineering, Islamic University, Kushtia 7003, Bangladesh.
}

\begin{tabular}{l}
\hline ARTICLE INFO \\
\hline Received on: $11 / 07 / 2019$ \\
Accepted on: 26/09/2019 \\
Available online: 05/02/2020 \\
\hline Key words: \\
Mikania cordata, methanol \\
extract, antibacterial activity, \\
Ehrlich ascites carcinoma, \\
anticancer activity.
\end{tabular}

\begin{abstract}
This study was aimed to screen the activity of the methanolic extract of Mikania cordata leaves (MLME) against pathogenic bacteria and Ehrlich ascites carcinoma (EAC)-induced cancer in mice. Antibacterial activity was tested against some Gram-positive (Bacillus subtilis IFO 3026 and Sarcina lutea IFO 3232) and Gram-negative (Klebsiella pneumoniae ATTC 10031, Proteus vulgaris MTTC 321, Pseudomonas denitrificans KACC 32026, and Xanthomonas campestris IAM 1671) bacteria by disk diffusion and liquid microdilution assay. The anticancer activity was assessed by EAC cell death, apoptosis, hematological parameters determination, and 3-(4, 5-dimethyl-2-thiazolyl)-2, 5-diphenyl-2H-tetrazolium bromide test. The MLME exhibited prominent antibacterial activity against the test strains. The minimum inhibitory concentrations were ranged from 1.25 to $20 \mathrm{mg} / \mathrm{ml}$ for the bacterial strains that were found ampicillin resistant. The MLME exhibited remarkable anticancer activity on EAC in a dose-dependent manner. Oral intake of MLME at the dosage of $400 \mathrm{mg} / \mathrm{kg}$ body weight (b.w) exhibited the highest EAC cell death with remarkable apoptotic features including chromatin condensation, nuclear fragmentation, and accumulation of apoptotic bodies. The MLME-treated EAC-bearing mice showed dose-dependently restored altered hematological parameters toward the normal level. The $\mathrm{IC}_{50}$ value was $6.6 \pm 1.91 \mu \mathrm{g} / \mathrm{ml}$. These findings suggest that the $M$. cordata leaves have strong antibacterial and anticancer properties.
\end{abstract}

\section{INTRODUCTION}

Pathogenic microbes, such as bacteria, viruses, parasites, and fungi are the causal agent of communicable diseases, which are reflected as a significant hazard to human health due to the scarcity of vaccines, inadequate chemotherapy, and an increase in resistant bacteria against antibiotics (Assob et al., 2011). Utmost of the

\section{${ }^{*}$ Corresponding Author}

Md. Mashiar Rahman, Molecular and Cellular Biology Laboratory,

Department of Genetic Engineering and Biotechnology,

Jashore University of Science and Technology, Jashore 7408, Bangladesh.

E-mail:mm.rahman@just.edu.bd contemporary antibiotics have extensive limitations regarding lower antimicrobial spectrum and side effects on the host including allergic reactions, immune-suppression, and hypersensitivity (Blumenthal et al., 2019; Londonkar et al., 2013). Moreover, their indiscriminate and inappropriate usage has led to the increasing clinical resistance of formerly sensitive microorganisms (Ventola, 2015). New and reemerging infectious diseases are rising very rapidly. Hence, this warns the looking for novel antimicrobial drugs, which will be natural, safe, and effective without side effects. Cancer is the second foremost cause of death after a cardiac disease that claimed 8.7 million deaths globally in 2015 (Global Burden of Disease Cancer Collaboration et al., 2017). In 2015, about 17.5 million new cases of cancer occurred and this number is predicted to be increased by 70 percent in the next 20 years (Siegel et al., 2015). Cancer occurs when 
cells with non-repaired damaged DNA grow, divide, and spread abnormally instead of self-destruction by programmed cell death. These types of unregulated atypical cells when invading other parts of the body normally initiate the progression that is called metastasis (Hanahan et al., 2011). Currently, the management of this condition is limited to the single and/or combined use of chemotherapy, radiotherapy, and surgery. Although these options are advancing significantly with higher survival rates, they are more or less costly with various side effects likely the reduction of neighboring normal cells, serious post-treatment complications, and in some cases, the resurrection of chemotherapy and radiotherapy resistant secondary malignancies (Al-Mamun et al., 2016; Islam et al., 2018). Therefore, the exploration of safer antitumor candidates with the least side effects and better selectivity is a big interest worldwide today.

Phytochemicals derived from medicinal plants have been reported to possess significant antiproliferative potential over the last two decades (Al-Dabbagh et al., 2019; Islam et al., 2014; Zhong et al., 2018). These studies reported that medicinal plant is a good source of antioxidants such as phenolics, flavonoids, vitamins, and carotenoids, and the intake of these plants either in the provision of chemical components or fresh extracts is mainly related with the lower risk of degenerative diseases including cancer (Demain and Vaishnav, 2011). Polyphenols such as apigenin, luteolin, myricetin, genistein, daidzein, quercetin, epigallocatechin gallate, cyanidin, curcumin, resveratrol, ferulic acid, nobiletin, diosmetin, and ellagitannins have been reported to possess strong anticancer properties (Goh et al., 2019; Tavsana and Kayalia, 2019; Tomeh et al., 2019). Moreover, about $60 \%$ of the modern anticancer drugs that are used in pharmaceutical industries are largely extracted from natural origins (Islam et al., 2014). Current anticancer drug targets one specific pathway whereas phytochemicals exhibit their anticancer effect by targeting numerous apoptotic signaling pathways which are reflected as the vital event in the anticancer activity (Demain and Vaishnav, 2011). Phytomolecules are now at the center of attraction in treating different cancer types as they are selective in their actions and specific only for the cancer cells. Several promising modern anticancer drugs of plant origin have been reported in recent times due to their success in managing abnormal cellular proliferation. Vinca alkaloids (vinorelbine, vindesine, vincristine, and vinblastine), taxanes (docetaxel and paclitaxel), campothecin derivatives, cephalotaxus, capsaicin, gingerol, cyanidin glycosides, lycopene, saffron (crocetin), resveratrol, apigenin, vitamin D and E from plant oil, kaempferol, genipin, lupeol, ellipticin, ecombretastatins, triterpenoid acids, etc., from plant, animal, and aquatic origins are among the many natural substances possessing anticancer activity (Gao et al., 2017; Iqbal et al., 2017; Lichota and Gwozdzinski, 2018; Nelius et al., 2016). Most of these phytochemicals are also effective in inhibiting the growth as well as killing a wide range of bacterial cells. Therefore, the demand for plant-based bioactive agents is increasing for chemotherapeutic purposes as they are natural, easily oral consumption as part of a patient's dietary intake, more tolerated, and non-toxic to normal human cells (Desai et al., 2008).

Mikania is the plant of Asteraceae family, having around 450 species, is found all over the tropical areas of Asia, Africa, South America, and Bangladesh. The Mikania species have been demonstrated to comprise numerous bioactive phytocomponents such as polyphenols, flavonoids, alkaloids, steroids, gums, tannins, saponins, and sesquiterpenes (Brigida da Silva et al., 2018). Among the Mikania species, M. cordata, also known as
Heartleaf Hempvine, is a twining and trailing woody-stemmed perennial herb characterized by its ovate heart-shaped leaves with 4-10 cm long with a pointed tip and truncate base, whitish flowers, capitulum inflorescence, white pappus, and narrowly oblong cypsela type of fruits (Ali et al., 2011). The local name of M. cordata is Assamlata or Taralata in Bangladesh and is found all over the country. The traditional use of various parts of the plant in Bangladesh is to treat a snake bite, coughs, diabetes, jaundice, septic sore, muscle spasms, colds, influenza, fever, bronchitis in children, and to stop bleeding from wounds and cuts. It is also used in the preparation of traditional herbal medication for the treatment of pain, inflammation, and infectious diseases (Nayeem et al., 2011). Different pharmacological properties of M. cordata tested in experimental animals had been reported. The ethanol extract of leaves has been evaluated for its anti-diarrheal activity and the anti-ulcerogenic effect in Long Evans rats (Brigida da Silva et al., 2018). The essential oil, and ethyl acetate and chloroform extracts from aerial parts have been described for its anti-nociceptive, anti-inflammatory, and antipyretic activities in experimental animals (Siddiqui et al., 2018). Although in vitro anticancer potentiality against human breast adenocarcinoma cell line has been demonstrated for ethanol extract of leaves of M. cordata (Uy et al., 2015), there are no scientific reports regarding the assessment of in vivo anticancer activities in Ehrlich ascites carcinoma (EAC) cell. Therefore, this study tested methanol extract of $M$. cordata leaves for its antibacterial activity against pathogenic bacteria and anticancer activity against EAC cancer cell in mice.

\section{MATERIALS AND METHODS}

\section{Reagents and chemicals}

Trypan blue, Dimethylsulfoxide (DMSO), Vincristine sulfate, Dulbecco's Modified Eagle Medium (DMEM), Fetal Bovine Serum (FBS), Penicillin-streptomycin, and 3-(4, 5-dimethyl-2-thiazolyl)-2, 5-diphenyl-2H-tetrazolium bromide (MTT) solution were purchased from Thermo Fisher Scientific, USA. Standard antibiotic disks and methanol were procured from Bio-Rad, USA and Merck, Germany, respectively. Nutrient agar media and nutrient broth media were obtained from Liofilchem, Italy. All other reagents and chemicals used in this work were of reagent rating and bought from Sigma-Aldrich Corporation, Germany.

\section{Plant material}

Mikania cordata leaves were collected from Jashore, Bangladesh and authenticated at Bangladesh National Herbarium, Dhaka (voucher number DACB 42864). The collected leaves were washed with tap water and dried at room temperature $\left(\sim 28^{\circ} \mathrm{C}\right)$ in shade. The leaves were ground into fine powder by a blender and stowed in the sealed vessel until subjected to solvent extraction.

\section{Preparation of plant extract}

The extraction of plant product was carried out according to the method described earlier with slight modification (Al-Mamun et al., 2016). A total of 1,200 $\mathrm{g}$ of leaves powder was distributed in eight $500 \mathrm{ml}$ conical flasks. Each flask was added with $400 \mathrm{ml}$ of absolute methanol and kept for 72 hours at $160 \mathrm{rpm}$ in a shaking incubator at $37^{\circ} \mathrm{C}$ and thereafter centrifuged for 15 
minutes at $8,000 \mathrm{rpm}$. The resulting pellets were dissolved again in absolute methanol and retained back in shaking incubator for 48 hours. The supernatants were collected and filtered through Whatman filter paper (No.1) and the filtrate was concentrated by a vacuum evaporator (Stuart, UK). After complete evaporation of water, the crude extract was stored at $4^{\circ} \mathrm{C}$.

\section{Antibacterial activity assay}

The antibacterial potentiality of the crude extract was tested by the disk diffusion method (Bubonja-Sonje et al., 2011). The bacterial pure cultures used in this study were Bacillus subtilis IFO 3026, Sarcina lutea IFO 3232, Klebsiella pneumonia ATTC 10031, Proteus vulgaris MTTC 321, Pseudomonas denitrificans KACC 32026, and Xanthomonas campestris IAM 1671. The crude methanol extract was dissolved into DMSO and each disk $(6 \mathrm{~mm}$ diameter) of Whatman filter paper (No. 1) was soaked with $10 \mu \mathrm{l}$ of $20 \mathrm{mg} / \mathrm{ml}(200 \mu \mathrm{g} /$ disk) of $M$. cordata leaves (MLME) and airdried. Blank disks soaked with DMSO and were used as a negative control. The ready disks were employed on a nutrient agar plate spread with $100 \mu \mathrm{l}$ of tested bacterial broth culture and incubated at $37^{\circ} \mathrm{C}$ for 24 hours. Standard antibiotics, i.e., Tetracycline at 30 $\mu \mathrm{g} /$ disk, Erythromycin at $15 \mu \mathrm{g} /$ disk, Ampicillin at $10 \mu \mathrm{g} / \mathrm{disk}$, and Ciprofloxacin at $5 \mu \mathrm{g} /$ disk were used as the positive control. After incubation, the culture plates were observed and the inhibition zones formed around each disk were measured in the millimeter scale (Dash et al., 2013). Minimum inhibitory concentration (MIC) of MLME was determined by liquid microdilution assay as previously described by Chandrasekaran and Venkatesalu (2004).

Experimental animal, ethics statement, and EAC cell transplantation

Swiss albino mice (25-30 g) of the male sex were purchased from the Pharmacy Department of Jahangirnagar University, Bangladesh. A total number of 162 mice were obtained and kept in the animal house of the Department of Biochemistry and Molecular Biology, University of Rajshahi, Bangladesh. The handling of mice and the methodology applied in this study was approved by the Animal, Medical Ethics, Biosafety and Biosecurity Committee (IAMEBBC) of University of Rajshahi, Bangladesh (no: 31/320/IAMEBBC/IBSC). EAC cell used in this study was kindly provided by Professor Dr. Md. Abu Reza, Protein Science Laboratory, Department of Genetic Engineering and Biotechnology, University of Rajshahi, Bangladesh. EAC cells were reared by weekly i.p of EAC cells in mice by succeeding transplantation of $6 \times 10^{6}$ cells in $0.2 \mathrm{ml}$ phosphate-buffered saline (PBS)/mice (Al-Mamun et al., 2016).

\section{Selection of appropriate dosages}

An acute oral toxicity assessment was performed according to the Organization for Economic Co-operation and Development (OECD) guidelines (Test no. 425) to select the suitable dosage of MLME for the evaluation of the anticancer activity. Briefly, a total of 66 mice were distributed into eleven groups each with six mice. Each group of mice (groups I, II, III, IV, V, VI, VII, VIII, IX, X, and XI) was administered orally with $0.2 \mathrm{ml}$ of MLME at the concentration of 12.5, 25, 50, 100, 200, 400, 800, 1,600, 3,200, 4,800, and 6,400 mg per $\mathrm{kg} \mathrm{b.w,}$ respectively. Each mouse of group XI which was untreated control was orally administered with $0.2 \mathrm{ml}$ of $2 \%$ DMSO in PBS. After treatment, mice were permitted to feed ad libitum and were closely monitored for the next 24 hours for any behavioral, neurological, and autonomic profiles and the 14 days for mortality. From these data, the percent $(\%)$ of mice mortality was enumerated for each concentration using the following formula:

$$
\% \text { mortality }=N_{\mathrm{d}} / N_{\mathrm{t}} \times 100
$$

(where $N_{\mathrm{d}}=$ Number of the dead mouse in each group; $N_{\mathrm{t}}=$ Number of mice taken in each group for testing, i.e., 6).

\section{Determination of EAC cell death in vivo}

The assessment of in vivo cancer cell death was performed according to the previously described method with slight modification (Rahman et al., 2017). In brief, a total of 36 mice were distributed into six groups (six in each group) and provided food and water ad libitum. All mice in each group were i.p injected with a volume of $0.2 \mathrm{ml}$ of EAC cells $\left(1 \times 10^{6}\right.$ cells/mouse $)$ suspended in PBS. Following 24 hours of post-EAC transplantation, each mouse of groups I, II, and III were treated with $0.2 \mathrm{ml}$ of MLME at the concentration of 100, 200, and $400 \mathrm{mg}$ per $\mathrm{kg}$ b.w (p.o), respectively, for therapeutic evaluation and continued for 6 days. Every mouse of group IV (positive control group) was injected with $0.2 \mathrm{ml}$ of vincristine sulfate (VS) i.p at the concentration of $300 \mu$ g per kg b.w. Group V (negative control group) was orally administered with the same volume of $2 \%$ DMSO in PBS. The group VI was untreated and served as the EAC control. After 6 days of treatment, three mice from each group were sacrificed on day 7. The appropriate amount of EAC cells were collected by the repeated i.p wash with PBS and harvested in cold PBS. Viable EAC cell counts by Trypan blue dye were made with a hemocytometer. The total number of viable EAC cells per mice of the treatment group was compared with those of the EAC control group. The EAC cell death was enumerated using the following formula:

$$
\begin{aligned}
\text { Cells } / \mathrm{ml}= & \text { the cells count in the central square } \times \\
& \text { the dilution factor } \times 10^{4} .
\end{aligned}
$$

The number of viable EAC cells of the treatment group was compared with those of the EAC control group. The cell death was enumerated using the following formula:

$$
\% \text { Cell death }=\left(C_{\mathrm{w}}-T_{\mathrm{w}}\right) / C_{\mathrm{w}} \times 100 .
$$

where $C_{\mathrm{w}}=$ average number of viable EAC cells in the EAC control group and $T_{\mathrm{w}}=$ average number of viable EAC cells in the treated group.

\section{Apoptosis evaluation by 4', 6-diamidino-2-phenylindole (DAPI) staining}

The apoptosis was determined by the previously described method with minor modifications (Al-Mamun et al., 2016). One milliliter $(1 \mathrm{ml})$ EAC cells from each group (groups I to VI) of mice were centrifuged for 3 minutes at $1,200 \mathrm{rpm}$. After that, the cell pellet was washed with PBS three times each with 3-minute centrifugation at 1,200 rpm. The cells were mixed with $5 \mu$ of 4', 6-diamidino-2-phenylindole (DAPI) solution and incubated in dark. After 10 minutes incubation, PBS was added to the DAPI containing pellet and centrifuged for 3 minutes at $1,200 \mathrm{rpm}$. Last, the cell pellet was dissolved in $200 \mu \mathrm{l}$ of PBS and 
$10 \mu \mathrm{l}$ cell suspensions were mounted on a glass slide to observe morphological changes of EAC cells by fluorescence microscope (XDS-2FL, Optika, Italy).

\section{Hematological studies of blood parameters}

To see the effect of MLME on the hematology of EAC cell-bearing mice, they were separated into six groups. Groups II to VI except for group I (control group) had been injected i.p on day zero with $0.2 \mathrm{ml}$ of EAC cells $\left(1 \times 10^{6}\right.$ cells/mouse). Group II was marked as the EAC control group. One day after EAC cell inoculation, MLME at the dosages of 100, 200, and $400 \mathrm{mg}$ per kg b.w was administered orally into the groups III, IV, and $\mathrm{V}$, respectively, and group VI was considered as positive control received vincristine sulfate at the concentration of $300 \mu \mathrm{g}$ per $\mathrm{kg}$ b.w. $2 \%$ DMSO in normal PBS at a volume of $5 \mathrm{ml} / \mathrm{kg}$ b.w was administered to the group I (untreated control group). Treatments were continued for 12 days and in each group, six male mice were handled. On the day of 13, blood was collected from the freely flowing tail vein and the total numbers of white blood cell (WBC) and red blood cell (RBC), and the percentage of hemoglobin and differential WBC (monocyte, lymphocyte, and neutrophil) counts were determined by previously described methods (Kathiriya et al., 2010).

\section{Determination of cytotoxicity by MTT assay}

To assess the cytotoxicity of MLME against EAC cell in vitro, MTT assay was performed by the previously described method with minor modification (Ramos-Silva et al., 2017). The EAC cells were inoculated at a density of $1 \times 10^{6}$ cells per well into a 96 well plate containing DMEM supplemented with $10 \%$ FBS and $100 \mathrm{U} / \mathrm{ml}$ penicillin-streptomycin and incubated at $37^{\circ} \mathrm{C}$ with $5 \% \mathrm{CO}_{2}$ and $95 \%$ air. After $75 \%$ of the confluence of the cells, they were added with $3.125,6.25,12.5,25,50$, and $100 \mu \mathrm{g} /$ $\mathrm{ml}$ concentrations of MLME separately. The control cells were treated with $2 \%$ DMSO in normal PBS. After 24 hours incubation, the medium was aspirated carefully, and the 96 well plates were gently washed with PBS. Twenty microliters of $5 \mathrm{mg} / \mathrm{ml}$ of MTT solution were dispensed into each well of both the MLMEtreated and DMSO-treated cells and allowed to react at $37^{\circ} \mathrm{C}$ in the dark. The supernatant was discarded after 8 hours incubation and $150 \mu \mathrm{l}$ of DMSO was used to dissolve the formazan. The optical density of every well was determined at $570 \mathrm{~nm}$ by using the Multiskan EX Microplate Reader (Thermo Fisher Scientific, USA). The percent of cell viability and death were enumerated by the following equation:

$$
\begin{aligned}
\text { Cell viability }(\%)= & {[\text { optical density }(\mathrm{OD}) \text { of treated }} \\
& \text { cells } / \mathrm{OD} \text { of control cells }] \times 100
\end{aligned}
$$

$$
\text { Cell death }(\%)=100-\text { Cell viability }(\%) \text {. }
$$

Cytotoxicity was represented as the concentration of MLME inhibiting cell growth by $50 \%\left(\mathrm{IC}_{50}\right.$ value $)$.

\section{Statistical analysis}

Values are represented as mean \pm standard deviation (STDEV) of the average of triplicate experiments is only for antibacterial activity and MTT assay. The statistical test was performed using one-way analysis of variance (ANOVA) using Origin Lab version 7. The post-hoc tests after one-way ANOVA used in this study were Bonferroni and Tukey Tests. Regression line analysis for the determination of lethal dosage $\left(\mathrm{LD}_{50}\right)$ and $\mathrm{IC}_{50}$ values were done by Microsoft Office Excel 2010. $p<0.05\left(^{*}\right), p<0.01(* *)$, and $p<0.001(* * *)$ were considered to be statistically significant, highly significant, and very highly significant, respectively, when treatment effects were compared with the control values.

\section{RESULTS AND DISCUSSION}

The plants are the natural reservoirs of biologically active secondary metabolites that have the potentials to combat different diseases (Dash et al., 2013). The metabolites derived from the green leaves of $M$. cordata comprise polyphenols, terpenoids, alkaloids, steroids, gums, and phytosterols (Iriti and Faoro 2009; Rufatto et al., 2012). These metabolites arise from the main secondary metabolic itineraries have wide-ranging antibiotic, powerful antioxidant, and anticancer activities (Iriti and Faoro, 2009). Therefore, we investigated the pharmacological effects of $M$. cordata leaves extract for its antibacterial and anticancer activities with the prospect of advancement in herbal medicinal plant research which will enable the development of newer antimicrobial and anticancer drugs and explore novel entities for specific targeting.

\section{MLME exhibited antibacterial activity}

The antibacterial potentiality of MLME against the test bacteria was examined by the occurrence of the clear zone of inhibition (Fig. 1A). The leaves extract at $200 \mu \mathrm{g} /$ disk concentration showed significant antibacterial effects against two Gram-positive bacteria (B. subtilis and $S$. lutea) and three Gramnegative bacteria ( $K$. pneumoniae, $P$. vulgaris, and $P$. denitrificans) with the zone of inhibition ranging from $11 \pm 0.816$ to $13 \pm 0.816$ $\mathrm{mm}$. This result indicates the broad-spectrum antibacterial activity of MLME. As shown in Figure 1B, the highest zone of inhibition was found as $13 \pm 0.816 \mathrm{~mm}$ against $S$. lutea, $P$. vulgaris, and $P$. denitrificans. The inhibition zone was observed as $11 \pm 0.816 \mathrm{~mm}$ against $K$. pneumoniae whereas the zone of inhibition was $12 \pm$ $0.816 \mathrm{~mm}$ against $B$. subtilis. Though all the test bacteria showed resistance against ampicillin, the test plant extract exhibited potent antibacterial activity. However, the reference antibiotics: tetracycline, erythromycin, and ciprofloxacin as positive control showed antibacterial activity, which is higher than that of the plant leaves extract exhibited. The previous study revealed that $M$. cordata leaves have various bioactive compounds, which might show antibacterial activity due to either individual or combined penetration of the outer phospholipidic layer of Gram-negative bacteria and peptidoglycan layer of Gram-positive bacteria (Ali et al., 2011). However, this antibacterial activity exhibited by the methanol extract may be attributed to the presence of some polar and non-polar bioactive constituents persisting in the methanol extract as this solvent is an amphiphilic compound that can extract more of the extractives of polar molecules and also non-polar ones (Londonkar et al., 2013). As shown in Table 1, the results of the minimum inhibitory concentration revealed that the antibacterial activity of the MLME is concentration-dependent. The MIC values for tested Gram-positive bacteria were 5 to $20 \mathrm{mg} / \mathrm{ml}$ while for Gram-negative bacteria this range was 1.25 to $10 \mathrm{mg} / \mathrm{ml}$ (Table 1). The best MIC was $1.25 \mathrm{mg} / \mathrm{ml}$ against $P$. vulgaris. The least efficacy 
was shown against $B$. subtilis. It is noticeable that all the test bacteria in this study showed antibiotic resistance against ampicillin while MLME showed potent antibacterial effect against all the tested bacteria. The necessity of searching natural plant products is justified to combat the growing resistance pattern of bacteria.

\section{Acute toxicity study to standardize dosage of MLME}

Acute toxicity study is related to the median $\mathrm{LD}_{50}$ was performed to select the suitable dosage of MLME for evaluation of the anticancer activity. As shown in Figure 2A, two-third of the mice died at the dosage of 3,200 $\mathrm{mg}$ per $\mathrm{kg}$ b.w after 3 hours and only one-third died at the dosage of 1,600 mg per $\mathrm{kg}$ b.w after

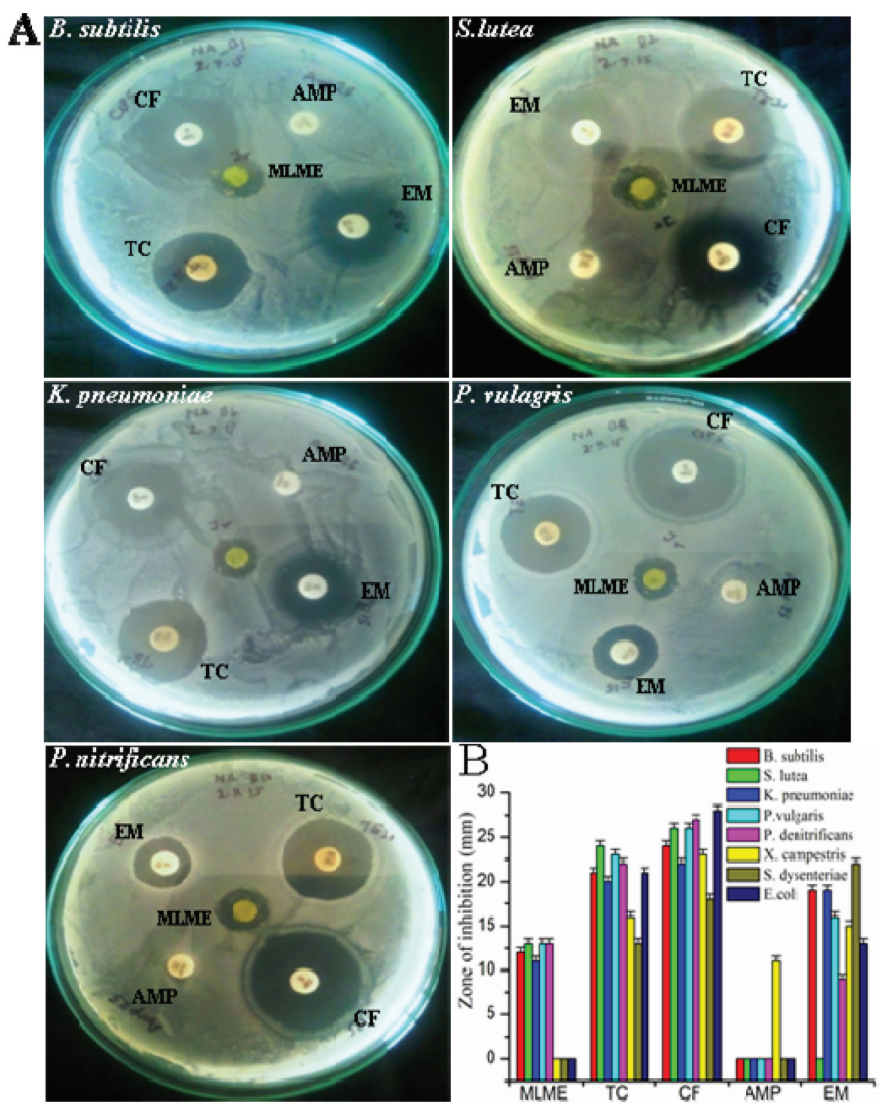

Figure 1. Antibacterial effect of MLME against Gram-positive and Gramnegative bacteria. (A) The zones of inhibition of bacterial growth by MLME and commercial antibiotics. (B) The ratios of zones of inhibition in millimeter ( $\mathrm{mm}$ ). Tetracycline (TC), Ciprofloxacin (CF), Ampicillin AMP) and Erythromycin $(\mathrm{EM})$ were used as positive control. Values are represented as mean $\pm \mathrm{STDEV}$ $(n=3)$.
11 hours. None of the mice died at the dosage of $800 \mathrm{mg}$ per $\mathrm{kg} \mathrm{b} . \mathrm{w}$. However, after 11 hours, no behavioral change symptoms, diarrhea, neither weight loss, nor any mortality was recorded during the next 13 hours and all along for 14 days in all MLME-treated groups. The oral $\mathrm{LD}_{50}$ value of the extract was $2836.851 \pm 61.781 \mathrm{mg}$ per $\mathrm{kg}$ b.w, which is above $2,000 \mathrm{mg}$ per $\mathrm{kg}$ b.w is a recommended nontoxic $\mathrm{LD}_{50}$ value by the OECD (Walum, 1998), suggesting that the lethal dosage is far greater than the effective anticancer dosage (i.e., 400 $\mathrm{mg}$ per $\mathrm{kg} \mathrm{b.w).} \mathrm{Therefore,} \mathrm{three} \mathrm{dosages} \mathrm{100,} \mathrm{200,} \mathrm{and} 400 \mathrm{mg}$ per kg b.w were selected for the present study. A similar study was performed by previous research (Debaprotim et al., 2014).

\section{MLME killed EAC cancer cells}

Generally, the cell count is determined by trypan blue dye staining. To assess the EAC tumor cell killing effect of MLME, the total number of viable EAC cell of the treatment group was compared with those of the control group (EAC untreated group) by hemocytometer counting of trypan blue dye staining. The cell count result showed that the viability of the EAC cell was decreased extensively by all dosages $(100,200$, and $400 \mathrm{mg}$ per $\mathrm{kg}$ b.w) of MLME in comparison with the control group (Fig. 3A). Microscopic observation of EAC cells from MLME-treated group and untreated control group showed that the viable EAC cells exclude trypan-blue dye and appear as white whereas dead EAC cells retained trypan-blue dye and viewed as blue, which indicates that MLME has EAC cancer cell killing effect. The percentage of EAC cancer cell death at the dosages of 100, 200, and $400 \mathrm{mg}$ per $\mathrm{kg}$ b.w of MLME was $46.536 \% \pm 1.82 \%, 54.942 \% \pm 1.559 \%$, and $66.386 \% \pm 1.287 \%$, respectively (Fig. 3B). The reference anticancer drug, vincristine sulfate at the dosage of $300 \mu \mathrm{g}$ per $\mathrm{kg}$ b.w showed $59.806 \% \pm 0.366 \%$ EAC cell death. Consistent with this result, it was reported that methanol extract of Eucalyptus camaldulensis (Islam et al., 2014) and Solanum schimperianum leaf(Almoulah et al., 2017) decreased the growth kinetics of EAC cancer cell. Thus, the MLME would be the potential source of the anticancer agent.

\section{MLME caused apoptosis in EAC cancer cell}

If natural products possess anticancer properties, they should have the apoptotic cell death mechanism. To test whether the anticancer effect of MLME was mediated by apoptosis, the morphological changes of EAC cells were microscopically observed by DAPI staining after 6 days of treatment of MLME and vincristine sulfate. As shown in Figure 4A, the critical morphological characteristics of apoptosis (chromatin condensation, nuclear fragmentation, and accumulation of

Table 1. Minimum inhibitory concentration of methanol extract of Mikania cordata leaves.

\begin{tabular}{lccccccc}
\hline & \multicolumn{7}{c}{ Minimum inhibitory concentration (mg/mL) } \\
\cline { 2 - 8 } & $\mathbf{2 0}$ & $\mathbf{1 0}$ & $\mathbf{5}$ & $\mathbf{2 . 5}$ & $\mathbf{1 . 2 5}$ & $\mathbf{0 . 6 2 5}$ & $\mathbf{0 . 3 1 2}$ \\
\hline Bacteria & & & \multicolumn{2}{c}{ Number of bacterial colonies survived at above concentration } & \\
\hline B. subtillis & 0 & $4 \pm 0.816$ & $9.333 \pm 1.247$ & $18.333 \pm 1.247$ & $22 \pm 1.632$ & $34.333 \pm 1.247$ & $42.666 \pm 1.247$ \\
S. lutea & 0 & 0 & 0 & $1.333 \pm 0.471$ & $3+0.816$ & $4.333 \pm 0.471$ & $11.333 \pm 1.247$ \\
K. pneumoniae & 0 & 0 & $8 \pm 0.816$ & $20.666 \pm 1.247$ & $52.666 \pm 2.054$ & $75.666 \pm 2.867$ & $90 \pm 2.160$ \\
P. vulgaris & 0 & 0 & 0 & 0 & 0 & $2.333 \pm 1.247$ & $3 \pm 0.816$ \\
P. denitrificans & 0 & 0 & $2 \pm 0.816$ & $11 \pm 1.632$ & $25 \pm 0.546$ & $39.333 \pm 2.867$ & $94.666 \pm 3.681$ \\
\hline
\end{tabular}


A

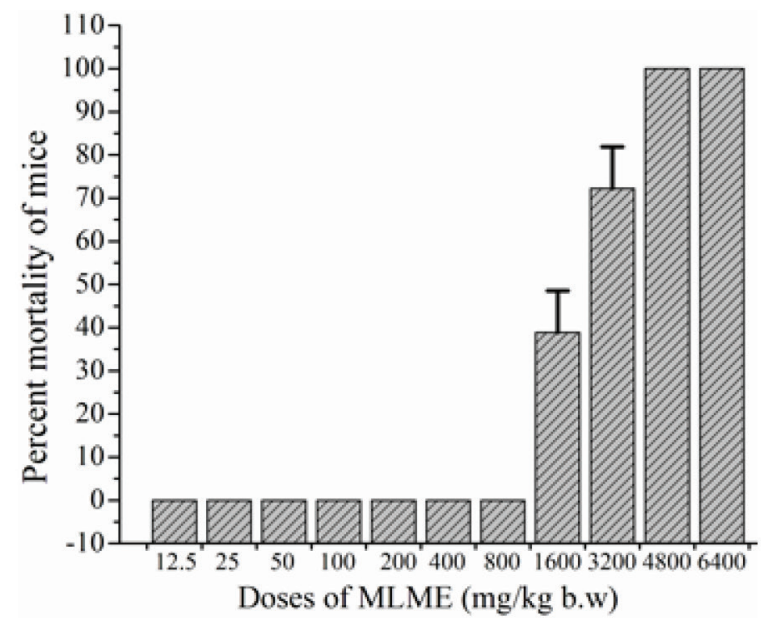

B

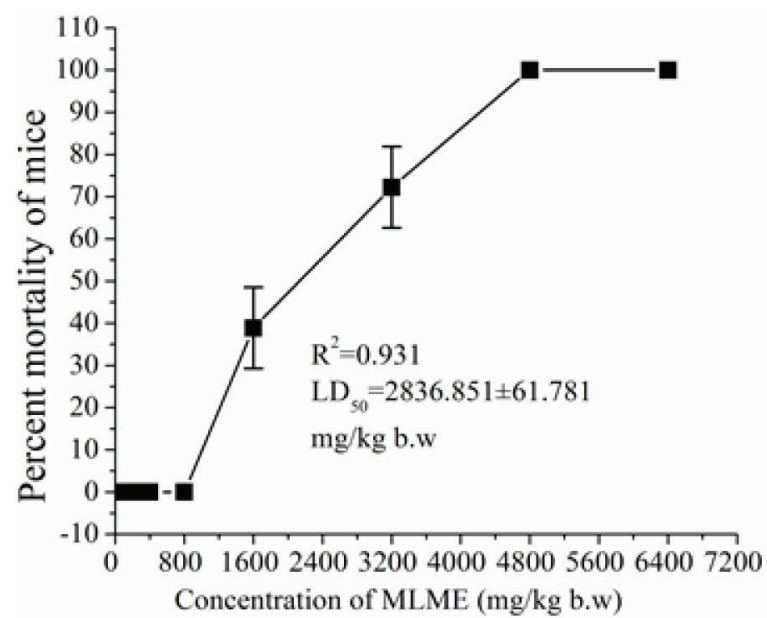

Figure 2. Acute toxicity study carried out by the oral administration of MLME in Swiss albino mice. (A) The selection of dosages of MLME upon oral administration of MLME. (B) The $\mathrm{LD}_{50}$ value of MLME was enumerated from the regression of MLME concentration versus percent mortality. The dosage, $2836.851 \pm 61.781 \mathrm{mg}$ per $\mathrm{kg}$ b.w was required to kill half the members of mice during 24 hours test duration.
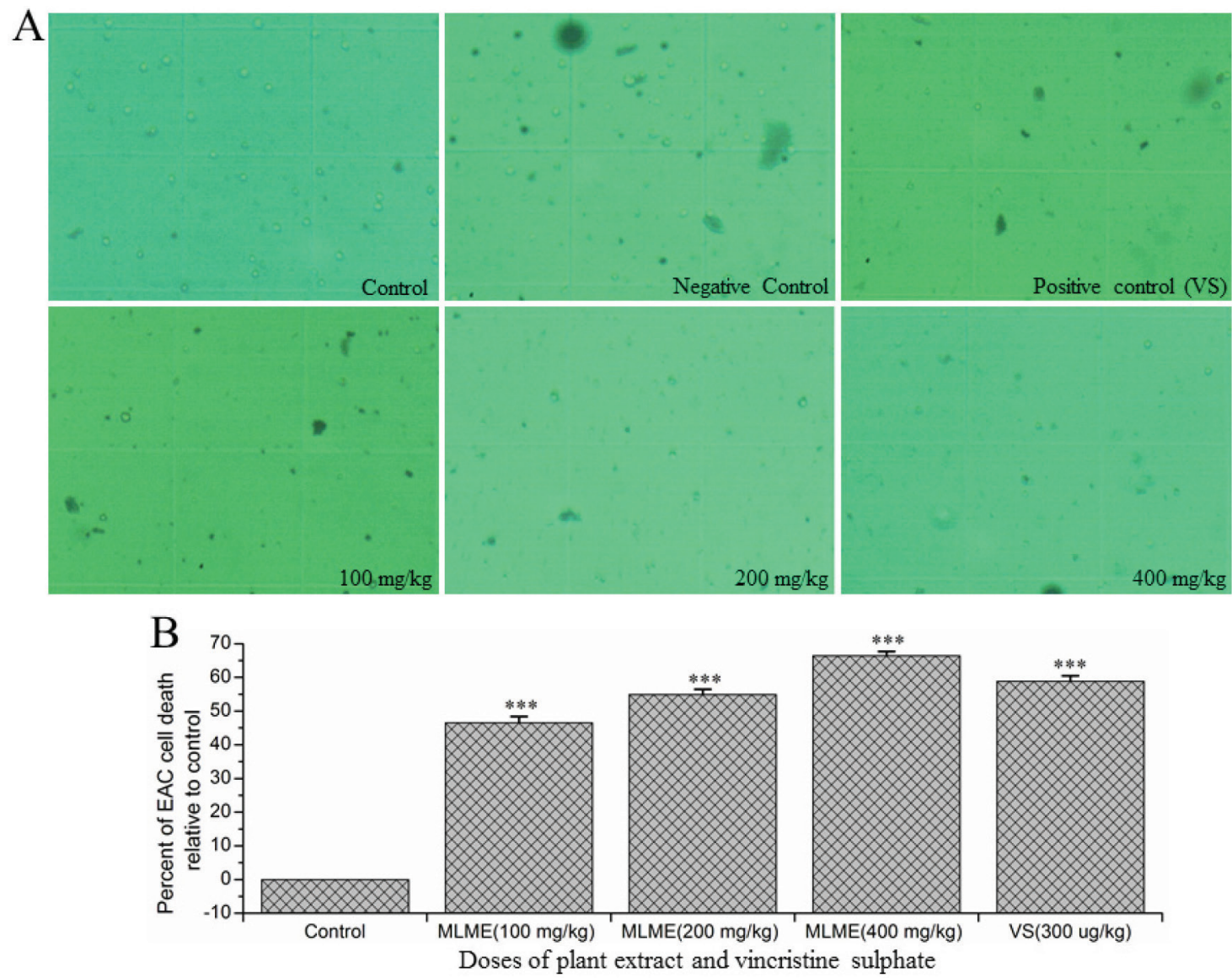

Figure 3. In vivo EAC tumor cell death by MLME at different dosages. (A) Hemocytometer counting of EAC tumor cells collected from both controls and treated groups of mice was determined using trypan blue dye after 6 days of EAC tumor cells transplantation. (B) Percentage of EAC tumor cell death on each dosage of MLME. Each value represents a mean $\pm \operatorname{STDEV}(n=6)$. The level of significance $* * *=p<0.001$ is very highly significantly different from untreated control. 

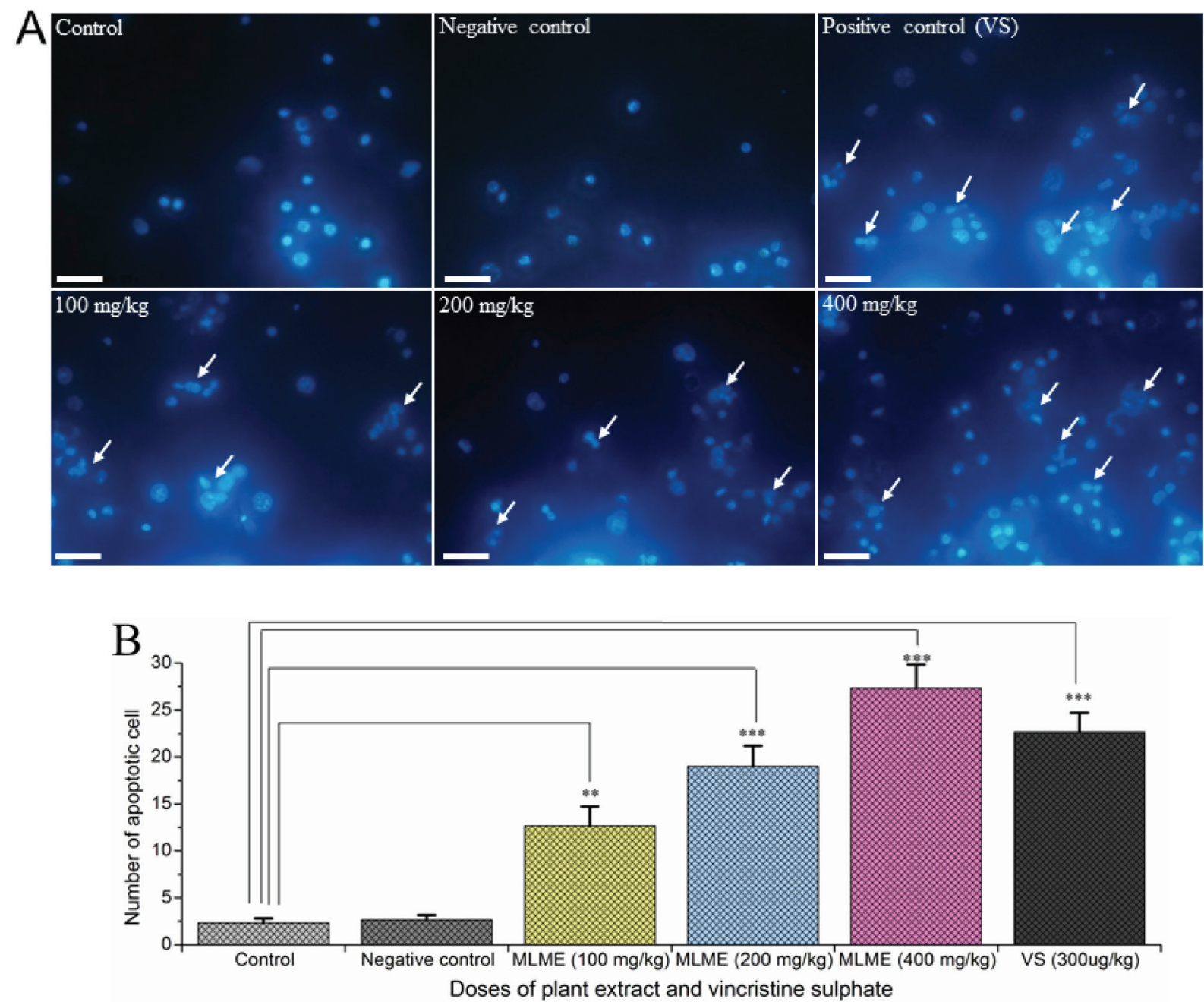

Figure 4. MLME induced apoptosis in EAC tumor cell. EAC cell bearing mice were treated for 5 days followed by collection of EAC tumor cells from MLME treated and non-treated EAC cell-bearing mice and subjected to stain with DAPI and observed by fluorescence microscope. (A) Marked apoptotic features such as nuclear condensation and fragmentation, and aggregation of apoptotic bodies were observed in the EAC tumor cells from treated groups in contrast to round-shaped control cells from the non-treated group. Arrows indicate apoptotic bodies of nuclear fragmentation observed at $40 \times$ magnification under an inverted fluorescence microscope. (B) The number of apoptotic cells per slide was estimated by counting apoptotic cells in five different fields. The values are expressed as mean $\pm \operatorname{STDEV}(n=6)$. The level of significance $* * *=p<0.001$ is very highly significant and $* *=p<0.01$ is highly significantly different from untreated control.

apoptotic bodies) were observed in the MLME-treated group and VS-treated group. Inhibition of the apoptotic pathway is a key event in tumor development, which allows the abnormal multiplication and growth of cells and promoting to the development of cancer. Thus, triggering apoptosis is deemed as the main approach and a useful indicator of almost every type of cancer treatment and prevention (Khan et al., 2015). The mean number of apoptotic cells is shown in Figure 4B. The results showed that the dose-dependent significant $(p<0.05)$ increase of the apoptotic EAC cells at the dosages of 100, 200, and $400 \mathrm{mg}$ per $\mathrm{kg}$ b.w of MLME-treated groups compared to control. The negative control did not show any apoptotic effect on EAC cell whereas positive control showed marked apoptotic features. Consistently, it was reported that methanol extract of E. camaldulensis caused EAC cell death by apoptosis (Islam et al., 2014).

\section{MLME prevent the alteration of hematological parameters in EAC cell-bearing mice}

As shown in Table 2 and Figure 5, the total numbers of WBC were significantly increased in the EAC control group $(p<0.01)$ compared with the untreated control group. Upon treated with MLME, WBC count was significantly decreased at the dosages of $200(p<0.05)$ and $400(p<0.01) \mathrm{mg}$ per kg b.w, respectively, in comparison with the untreated control group. Consistent with this result, anticancer drugs have also prolonged the lifespan and decrease the number of elevated WBC from the blood (Gayatri et al., 2015; Kathiriya et al., 2010). In a differential count, the presence of neutrophils was increased by $53.306 \% \pm 0.63 \%$ $(p<0.001)$ and monocytes and lymphocyte count were decreased significantly by $0.742 \% \pm 0.08 \%(p<0.05)$ and $41.24 \% \pm 0.91 \%$ $(p<0.001)$, respectively, in EAC control group in comparison with the untreated control group. In contrast, the treatment groups 
Table 2. Effect of Mikania cordata leaves extract on hematological parameters of EAC cell-bearing mice.

\begin{tabular}{|c|c|c|c|c|c|c|}
\hline Treatment groups & WBC $($ Cells $/ \mathrm{ml}) \times 106$ & RBC $($ Cells $/ \mathrm{ml}) \times 109$ & $\%$ of $\mathrm{Hb}(\mathrm{gm} / \mathrm{dl})$ & Monocytes (\%) & Lymphocytes (\%) & Neutrophils (\%) \\
\hline Normal Mice (GI) & $8.373 \pm 0.793$ & $6.92 \pm 0.139$ & $14.896 \pm 0.898$ & $1.653 \pm 0.413$ & $69.233 \pm 0.816$ & $22.523 \pm 0.717$ \\
\hline EAC bearing mice (GII) & $15.16 \pm 0.870^{\# \#}$ & $4.443 \pm 0.675^{\# \#}$ & $7.31 \pm 0.543^{\# \#}$ & $0.742 \pm 0.084^{\#}$ & $41.24 \pm 0.914^{\# \#}$ & $53.306 \pm 0.637^{\ldots \# \#}$ \\
\hline EAC + MLME $(100 \mathrm{mg} / \mathrm{kg})$ & $14.84 \pm 0.286^{\mathrm{NS}}$ & $5.303 \pm 0.408^{\mathrm{NS}}$ & $8.733 \pm 0.597^{\mathrm{NS}}$ & $1.17 \pm 0.183 *$ & $52.583 \pm 0.939 * * *$ & $38.49 \pm 0.694 * * *$ \\
\hline $\mathrm{EAC}+\mathrm{MLME}(200 \mathrm{mg} / \mathrm{kg})$ & $12.21 \pm 0.592 *$ & $6.1 \pm 0.163^{*}$ & $9.99 \pm 0.408 * *$ & $1.27 \pm 0.254^{*}$ & $59.41 \pm 1.061 * * *$ & $28.456 \pm 0.612 * * *$ \\
\hline $\mathrm{EAC}+\mathrm{MLME}(400 \mathrm{mg} / \mathrm{kg})$ & $10.186 \pm 0.571 * *$ & $6.783 \pm 0.184^{* *}$ & $12.563 \pm 0.449 * * *$ & $1.32 \pm 0.306^{* *}$ & $61.823 \pm 1.551 * * *$ & $24.456 \pm 0.530 * * *$ \\
\hline $\mathrm{EAC}+\mathrm{VS}(300 \mu \mathrm{g} / \mathrm{kg})$ & $10.16 \pm 0.796^{* *}$ & $6.9 \pm 0.163^{* *}$ & $12.876 \pm 0.396 * * *$ & $1.443 \pm 0.408 * *$ & $61.93 \pm 1.261 * * *$ & $24.1 \pm 1.512 * * *$ \\
\hline
\end{tabular}

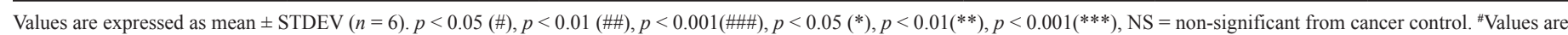
significantly different from untreated control, *Values are significantly different from EAC control.
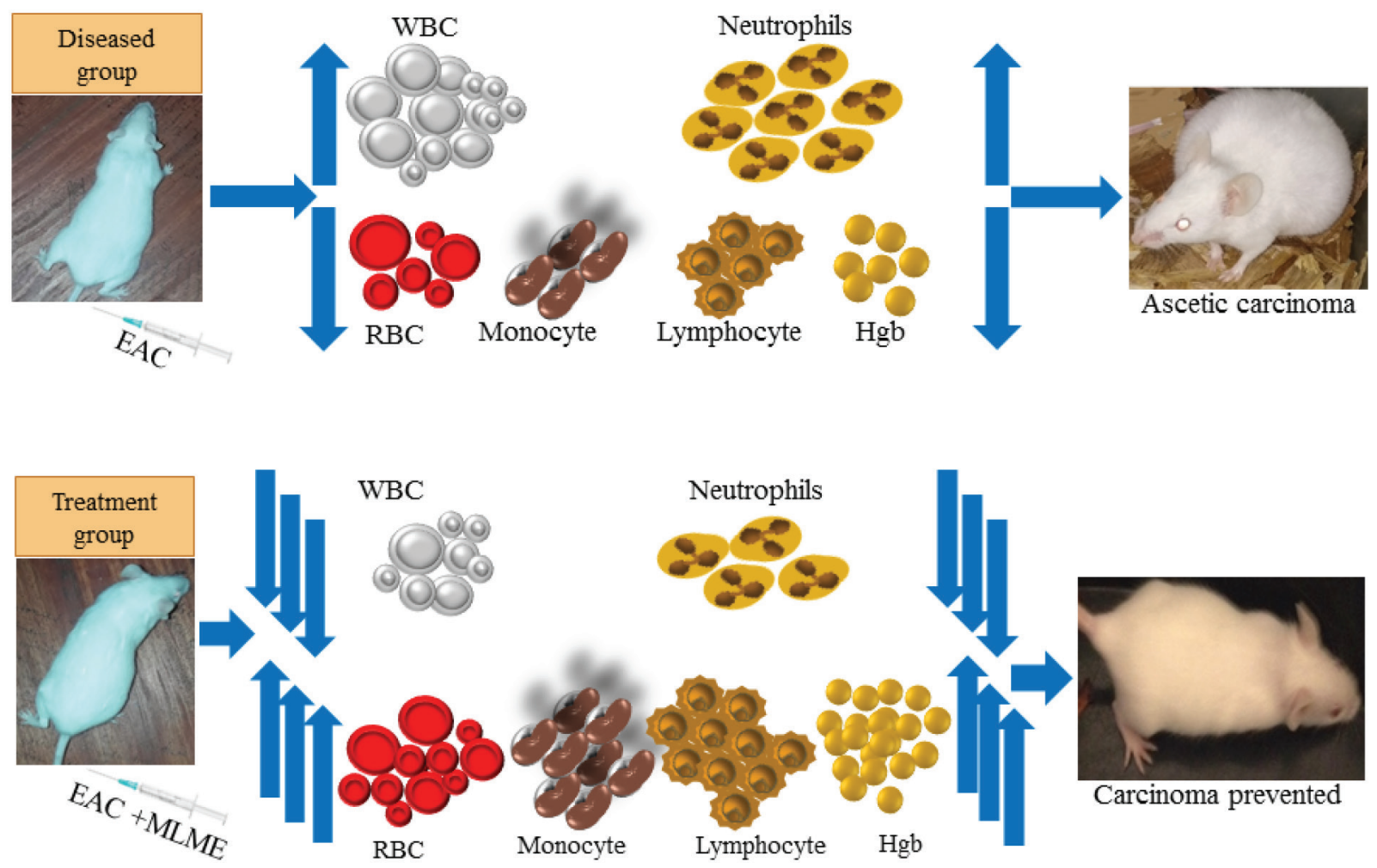

Figure 5. Schematic representation of the prevention of EAC tumor cell-induced altered hematological parameters by MLME. (A) Upon i.p injection of EAC cell into Swiss albino mice, WBC count and neutrophil percent were increased and RBC count and Lymphocytes, monocyte and hemoglobin percent were decreased and mice acquired ascetic carcinoma. (B) Treatment with MLME, the altered hematological parameters (rising of WBC and neutrophil count and reduction of RBC, Lymphocytes, monocyte, and hemoglobin) were restored towards normal level and mice recovered from ascetic carcinoma.

at the dosages of 100,200 , and $400 \mathrm{mg}$ per $\mathrm{kg}$ b.w, the percent of neutrophil was decreased $(p<0.001)$ by $38.49 \% \pm 0.69 \%, 28.456 \%$ $\pm 0.61 \%$, and $24.456 \% \pm 0.53 \%$, respectively. The percentage of monocytes at the dosages of 100, 200, and $400 \mathrm{mg}$ per $\mathrm{kg} \mathrm{b} . \mathrm{w}$ was increased by $1.17 \% \pm 0.18 \%, 1.27 \% \pm 0.25 \%(p<0.05)$, and $1.32 \% \pm 0.30 \%(p<0.01)$ and lymphocyte by $52.583 \% \pm 0.93 \%$, $59.41 \% \pm 1.06 \%$, and $61.823 \% \pm 1.55 \%(p<0.001)$, respectively. The plant-based standard drug, vincristine sulphate at the dosage of $300 \mu \mathrm{g}$ per $\mathrm{kg}$ b.w decreased the percent of a neutrophil by $24.1 \% \pm 1.51 \%(p<0.001)$ and increased the monocyte and lymphocyte by $1.443 \% \pm 0.40 \%(p<0.01)$ and $61.93 \% \pm 1.26 \%$ $(p<0.001)$, respectively. From the results, it was observed that neutrophil, monocyte, and lymphocyte count was restored towards the normal level, which indicates that MLME might have a direct protective effect against alteration of hematological parameters in EAC cell-bearing mice. The similar results were also observed by Nakajima et al. (2011). The percentage of hemoglobin $(p<0.001)$ and RBC count $(p<0.01)$ was significantly decreased in the EAC control group in comparison with the untreated control group. The reduction of RBC and the level of hemoglobin in EAC cell-bearing mice implicate the anemic condition. Upon treatment with MLME at the dosages of 100, 200, and $400 \mathrm{mg}$ per $\mathrm{kg} \mathrm{b.w}$, the percent of hemoglobin was increased by $8.733 \% \pm 0.59 \%, 9.99 \% \pm 0.40 \%$ $(p<0.01)$, and $12.563 \% \pm 0.44 \%(p<0.001)$, respectively, and $\mathrm{RBC}$ count was also increased significantly compared to EAC control group. Collectively, the above-mentioned hematological parameters revealed that MLME possesses protective action against cancer-induced altered effects on the hemopoietic system. 


\section{MLME caused cytotoxicity in EAC cell in Swiss albino mice}

As shown in Figure 6A, upon treatment with MLME at the dosages of $3.125,6.25,12.5,25,50$, and $100 \mu \mathrm{g} / \mathrm{ml}$, it was observed that EAC tumor cell death was increased in a dosedependent manner. The result showed that the number of viable EAC cells was found to be significantly decreased as the MLME concentration increased. The $\mathrm{IC}_{50}$ value was $6.6 \pm 1.91 \mu \mathrm{g} / \mathrm{ml}$ (Fig. 6B). The $\mathrm{IC}_{50}$ value indicates the amount of the extract which prevents the growth of $50 \%$ of the cell population. In MTT assay, the succinate dehydrogenase converts yellow MTT dye to formazan (purple crystals) in the mitochondria of viable cells. The purple formazan crystals were quantified by spectrophotometry to evaluate the magnitude of cytotoxicity and cell viability (Tiwary et al., 2015). Estimation of the half-maximal (50\%) inhibitory concentration $\left(\mathrm{IC}_{50}\right)$ of the anticancer agent is essential for understanding the magnitude of cytotoxic activity against
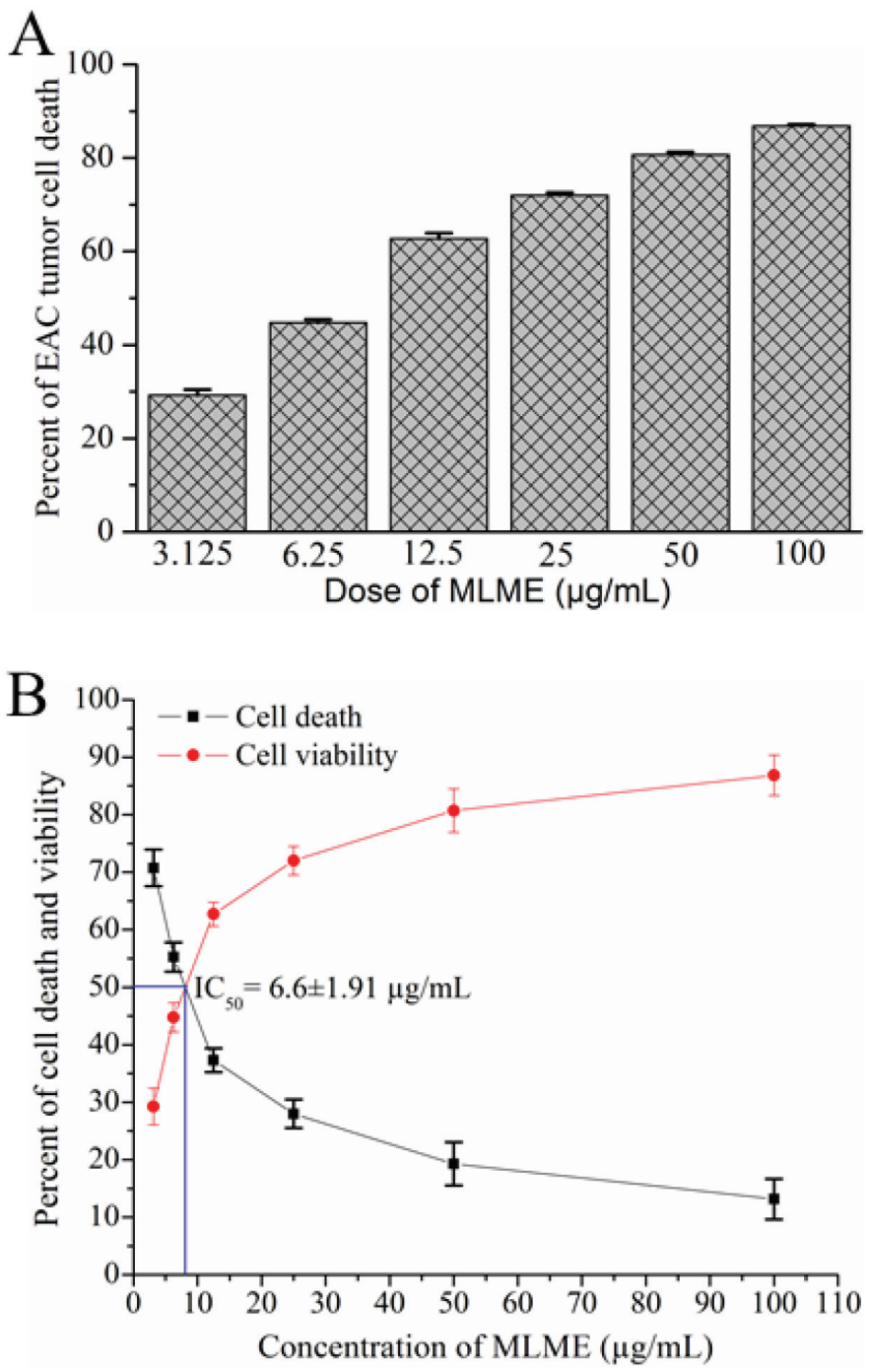

Figure 6. MLME caused cytotoxicity on EAC tumor cell determined by MTT assay in vitro. (A) Growth inhibition of EAC tumor cell upon treatment with different dosages of MLME for 24 hours. (B) The $\mathrm{IC}_{50}$ value of MLME was enumerated from the MLME concentration versus percent mortality. The values are represented as mean $\pm \operatorname{STDEV}(n=3)$. the cancer cell. The standards of cytotoxicity customized by the U.S. National Cancer Institute (NCI) plant screening program established a crude extract is inactive, moderately active, and active against cancer cell, if $\mathrm{IC}_{50}$ values are higher than $100 \mu \mathrm{g} /$ $\mathrm{ml}$, from 20 to $100 \mu \mathrm{g} / \mathrm{ml}$, and lower than $20 \mu \mathrm{g} / \mathrm{ml}$, respectively (Ramos-Silva et al., 2017). MLME exhibited the cytotoxic effect with an $\mathrm{IC}_{50}$ value of $6.6 \pm 1.91 \mu \mathrm{g} / \mathrm{ml}$, which is less than $20 \mu \mathrm{g} / \mathrm{ml}$. Accordingly, it supports the notion that the test extract is strongly cytotoxic to the EAC cell, which indicates its anticancer potential for further investigation.

\section{CONCLUSION}

The present study confirmed that the Mikania cordata leave extract has potent antibacterial and anticancer properties. MTT study results also supported the anticancer properties of Mikania cordata leave extract. These findings warrant advance studies for isolation and identification of the liable bioactive compounds and to explicate the mechanism(s) linking with the antibacterial and anticancer effects.

\section{ACKNOWLEDGMENTS}

The authors would like to thank Professor Dr. Md. Abu Reza of the Department of Genetic Engineering and Biotechnology, University of Rajshahi, Bangladesh for technical and laboratory support. The bacterial strains were obtained from the Department of Biotechnology and Genetic Engineering of Islamic University, Kushtia, Bangladesh.

\section{CONFLICTS OF INTEREST}

The authors declared that they have no conflicts of interest.

\section{FINANCIAL SUPPORT}

The National Science and Technology (NST) grant (Grant no.: 39.00.0000.09.06.79.2017/2 Gr. SL. BS 112) of the Ministry of Science and Technology of the People's Republic of Bangladesh supported this research work.

\section{REFERENCES}

Al-Dabbagh B, Elhaty IA, Elhaw M, Murali C, Al Mansoori A, Awad B, Amin A. Antioxidant and anticancer activities of chamomile (Matricaria recutita L.). BMC Res Notes, 2019; 12(1):3; doi:10.1186/ s13104-018-3960-y

Ali MS, Islam MS, Rahman MM, Islam MR, Sayeed MA, Islam MR. Antibacterial and cytotoxic activity of ethanol extract of Mikania cordata (Burm.f.) B.L. Robinson leaves. J Basic Clin Pharm, 2011; 2(2):103-7.

Al-Mamun MA, Husna J, Khatun M, Hasan R, Kamruzzaman M, Hoque KM, Reza MA, Ferdousi Z. Assessment of antioxidant, anticancer and antimicrobial activity of two vegetable species of Amaranthus in Bangladesh. BMC Complement Altern Med, 2016; 16(1):1-11.

Almoulah NF, Voynikov Y, Gevrenova R, Schohn H, Tzanova T, Yagi S, Thomas J, Mignard B, Ahmed AAA, El Siddig MA, Spina R, Laurain-Mattar D. Antibacterial, antiproliferative and antioxidant activity of leaf extracts of selected Solanaceae species. South Afr J Bot, 2017; 112:368-74.

Assob JCN, Kamga HLF, Nsagha DS, Njunda AL, Nde PF, Asongalem EA, Njouendou AJ, Sandjon B, Penlap VB. Antimicrobial and toxicological activities of five medicinal plant species from Cameroon traditional medicine. BMC Complement Altern Med, 2011; 11:70; doi:10.1186/1472-6882-11-70 
Brigida da Silva AS, Owiti A, Barbosa WR. Pharmacology of Mikania genus: a systematic review. Pharmacogn Rev, 2018; 12(24):230-7.

Bubonja-Sonje M, Giacometti J, Abram M. Antioxidant and antilisterial activity of olive oil, cocoa and rosemary extract polyphenols. Food Chem, 2011; 127(4):1821-7.

Chandrasekaran M, Venkatesalu V. Antibacterial and antifungal activity of Syzygium jambolanum seeds. J Ethnopharmacol, 2004; 91(1):105-8.

Dash BK, Sen MK, Alam K, Hossain K, Islam R, Banu NA, Rahman S, Jamal AHM. Antibacterial activity of Nymphaea nouchali (Burm. f) flower. Ann Clin Microbiol Antimicrob, 2013;12:27; doi:10.1186/14760711-12-27

Debaprotim D, Suvakanta D, Jashabir C. Evaluation of anticancer activity of Mikania micrantha Kunth (Asteraceae) against Ehrlich ascites carcinoma in Swiss albino mice. Int J Pharm. Res Allied Sci, 2014; 3(2):9-18.

Demain AL, Vaishnav P. Natural products for cancer chemotherapy. Microb Biotechnol, 2011; 4(6):687-99.

Desai A, Qazi G, Ganju R, El-Tamer M, Singh J, Saxena AK, Bedi YS, Taneja SC, Bhat HK. Medicinal plants and cancer chemoprevention. Curr Drug Metab, 2008; 9(7):581-91.

Gao C, Zhou Y, Jiang Z, Zhao Y, Zhang D, Cong X, Cao R, Li $\mathrm{H}$, Tian W. Cytotoxic and chemosensitization effects of Scutellarin from traditional Chinese herb Scutellaria altissima L. in human prostate cancer cells. Oncol Rep, 2017; 38(3):1491-49.

Gayatri C, Maheswara Reddy $\mathrm{Cu}$, Chitra K, Parthasarathy V. Assessment of in vitro cytotoxicity and in vivo antitumor activity of Sphaeranthus amaranthoides Burm.f. Pharmacogn Res, 2015; 7(2): 198-202.

Global Burden of Disease Cancer Collaboration, Fitzmaurice C, Allen C, Barber RM, Barregard L, Bhutta ZA, Brenner H, Dicker DJ, ChimedOrchir O, Dandona R, Dandona L, Fleming T, Forouzanfar MH, Hancock J, Hay RJ, Hunter-Merrill R, Huynh C, Hosgood HD, Johnson CO, Jonas JB, Khubchandani J, Kumar GA, Kutz M, Lan Q, Larson HJ, Liang X, Lim SS, Lopez AD, MacIntyre MF, Marczak L, Marquez N, Mokdad AH, Pinho C, Pourmalek F, Salomon JA, Sanabria JR, Sandar L, Sartorius B, Schwartz SM, Shackelford KA, Shibuya K, Stanaway J, Steiner C, Sun J, Takahashi K, Vollset SE, Vos T, Wagner JA, Wang H, Westerman R, Zeeb H, Zoeckler L, Abd-Allah F, Ahmed MB, Alabed S, Alam NK, Aldhahri SF, Alem G, Alemayohu MA, Ali R, Al-Raddadi R, Amare A, Amoako Y, Artaman A, Asayesh H, Atnafu N, Awasthi A, Saleem HB, Barac A, Bedi N, Bensenor I, Berhane A, Bernabé E, Betsu B, Binagwaho A, Boneya D, Campos-Nonato I, Castañeda-Orjuela C, Catalá-López F, Chiang P, Chibueze C, Chitheer A, Choi JY, Cowie B, Damtew S, das Neves J, Dey S, Dharmaratne S, Dhillon P, Ding E, Driscoll T, Ekwueme D, Endries AY, Farvid M, Farzadfar F, Fernandes J, Fischer F, G/Hiwot TT, Gebru A, Gopalani S, Hailu A, Horino M, Horita N, Husseini A, Huybrechts I, Inoue M, Islami F, Jakovljevic M, James S, Javanbakht M, Jee SH, Kasaeian A, Kedir MS, Khader YS, Khang YH, Kim D, Leigh J, Linn S, Lunevicius R, El Razek HMA, Malekzadeh R, Malta DC, Marcenes W, Markos D, Melaku YA, Meles KG, Mendoza W, Mengiste DT, Meretoja TJ, Miller TR, Mohammad KA, Mohammadi A, Mohammed S, Moradi-Lakeh M, Nagel G, Nand D, Le Nguyen Q, Nolte S, Ogbo FA, Oladimeji KE, Oren E, Pa M, Park EK, Pereira DM, Plass D, Qorbani M, Radfar A, Rafay A, Rahman M, Rana SM, Søreide K, Satpathy M, Sawhney M, Sepanlou SG, Shaikh MA, She J, Shiue I, Shore HR, Shrime MG, So S, Soneji S, Stathopoulou V, Stroumpoulis K, Sufiyan MB, Sykes BL, Tabarés-Seisdedos R, Tadese F, Tedla BA, Tessema GA, Thakur JS, Tran BX, Ukwaja KN, Uzochukwu BSC, Vlassov VV, Weiderpass E, Wubshet Terefe M, Yebyo HG, Yimam HH, Yonemoto N, Younis MZ, Yu C, Zaidi Z, Zaki MES, Zenebe ZM, Murray CJL, Naghavi M. Global, regional, and national cancer incidence, mortality, years of life lost, years lived with disability, and disability-adjusted life-years for 32 cancer groups, 1990 to 2015: a systematic analysis for the global burden of disease study. JAMA Oncol, 2017; 3(4):524-8.

Goh JXH, Tan LT, Goh JK, Chan KG, Pusparajah P, Lee LH, Goh BH. Nobiletin and derivatives: functional compounds from citrus fruit peel for colon cancer chemoprevention. Cancers, 2019; 11(6):867; doi:10.3390/cancers 11060867

Hanahan D, Weinberg RA. Hallmarks of cancer: the next generation. Cell, 2011; 144(5):646-74.

Iqbal J, Abbasi BA, Mahmood T, Kanwal S, Ali B, Shah SA, Khalil AT. Plant-derived anticancer agents: a green anticancer approach. Asian Pac J Trop Biomed, 2017; 7(12):1129-50.

Iriti M, Faoro F. Chemical diversity and defense metabolism: how plants cope with pathogens and ozone pollution. Int J Mol Sci, 2009; 10(8):3371-99.

Islam F, Khatun H, Khatun M, Ali SMM, Khanam JA. Growth inhibition and apoptosis of Ehrlich ascites carcinoma cells by the methanol extract of Eucalyptus camaldulensis. Pharm Biol, 2014; 52(3):281-90.

Islam MS, Rahi MS, Jahangir CA, Rahman MH, Jerin I, Amin $\mathrm{R}$, Hoque KMF, Reza MA. In vivo anticancer activity of Basella alba leaf and seed extracts against Ehrlich's ascites carcinoma (EAC) cell line. Evid Based Complement Altern Med, 2018; doi:10.1155/2018/1537896

Kathiriya A, Das K, Kumar E, Mathai KB. Evaluation of antitumor and antioxidant activity of Oxalis Corniculata Linn. against Ehrlich ascites carcinoma on mice. Iran J Cancer Prev, 2010; 3(4):157-65.

Khan M, Maryam A, Qazi JI, Ma T. Targeting apoptosis and multiple signaling pathways with icariside II in cancer cells. Int J Biol Sci, 2015; 11(9):1100-12.

Blumenthal KG, Peter JG, Trubiano JA, Phillips EJ. Antibiotic allergy. Lancet, 2019; 393(10167):183-98.

Lichota A, Gwozdzinski K. Anticancer activity of natural compounds from plant and marine environment. Int J Mol Sci, 2018; 19(11):3533; doi:10.3390/ijms19113533

Londonkar RL, Kattegouga UM, Shivsharanappa K, Hanchinalmath JV. Phytochemical screening and in vitro antimicrobial activity of Typha angustifolia Linn leaves extract against pathogenic gram negative microorganisms. J Pharm Res, 2013; 6(2):280-3.

Nakajima K, Nakajima Y. Carcinoma infection and immune systems of ehrlich ascites carcinoma-bearing mice treated with structurally similar sulfonium compounds. Biosci Biotechnol Biochem, 2011; 75(4):808-11.

Nayeem A Al, Khatun A, Rahman S, Rahman M. Evaluation of phytochemical and pharmacological properties of Mikania cordata (Asteraceae) leaves. J Pharmacogn Phytother, 2011; 3:118-23.

Nelius T, Jarvis C, Martinez-Marin D, Filleur S. Comparison of docetaxel and cabazitaxel efficacy on prostate cancer cells both in vitro and in vivo. J Clin Oncol, 2016;34 (suppl 2):351; doi:10.1200/jco.2016.34.2 suppl.351

Rahman MS, Alam MB, Choi YH, Yoo JC. Anticancer activity and antioxidant potential of Aponogeton undulatus against Ehrlich ascites carcinoma cells in Swiss albino mice. Oncol Lett, 2017; 14(3):3169-76.

Ramos-Silva A, Tavares-Carreon F, Figueroa M, De la TorreZavala S, Gastelum-Arellanez A, Rodriguez-Garcia A, Galan-Wong LJ, Avils-Arnaut H. Anticancer potential of Thevetia peruviana fruit methanolic extract. BMC Complement Altern Med, 2017; 17(1):241; doi:10.1186/ s12906-017-1727-y

Rufatto LC, Gower A, Schwambach J, Moura S. Genus Mikania chemical composition and phytotherapeutical activity. Braz J Pharmacogn, 2012; 22(6):1384-403

Siddiqui SA, Rahman A, Oliur Rahman M, Akbar MA, Shamsur Rouf AS, Ali MA, Al-Hemaid FMA, Farah MA. Evaluation of antinociceptive, anti-inflammatory and antipyretic potential of Mikania cordata (Burm. f.) Robinson in experimental animal model. Saudi J Biol Sci, 2018; 25(6):1049-55.

Siegel RL, Miller KD, Jemal A. Cancer statistics, 2015. CA Cancer J Clin, 2015; 65(1):5-29.

Tavsana Z, Kayalia HA. Flavonoids showed anticancer effects on the ovarian cancer cells: Involvement of reactive oxygen species, apoptosis, cell cycle and invasion. Biomed Pharmacother, 2019; 116:109004; doi: 10.1016/j.biopha.2019.109004

Tiwary BK, Bihani S, Kumar A, Chakraborty R, Ghosh R. The in vitro cytotoxic activity of ethno-pharmacological important plants of Darjeeling district of West Bengal against different human cancer cell lines. 
BMC Complement Altern Med, 2015; 15:22; doi:10.1186/s12906-0150543-5

Tomeh MA, Hadianamrei R, Zhao X. A review of Curcumin and its derivatives as anticancer agents. Int J Mol Sci, 2019; 20(5):1033; doi:10.3390/ijms20051033

Uy TGC, Licuanan AM, Angeles GED, Bote MLCC, Macauyag EAB, Hernandez CC, Jacinto SD, Guzman-Genuino RM. Anticancer effect and mechanisms of action of Mikania cordata plant extract on MCF-7 human breast adenocarcinoma cells. Int J Cancer Res, 2015;11(2):80-92.

Ventola CL. The antibiotic resistance crisis: Part 1: causes and threats. Pharm Ther, 2015; 40(4):277-83.

Walum E. Acute oral toxicity. Environ Health Perspect, 1998; 106 (Suppl 2):497-503.
Zhong Z, Yu H, Wang S, Wang Y, Cui L. Anticancer effects of Rhizoma curcumae against doxorubicin-resistant breast cancer cells. Chin Med, 2018;13(1):44; doi:10.1186/s13020-018-0203-z

How to cite this article:

Rahman MM, Kabir MM, Noman AAL, Islam MR, Dash BK, Akhter S, Uddin MJ, Rahman A. Mikania cordata leaves extract promotes activity against pathogenic bacteria and anticancer activity in EAC cell-bearing Swiss albino mice. J Appl Pharm Sci, 2020; 10(02):112-122. 